\title{
O universo emblemático das iluminogravuras de Ariano Suassuna
}

\section{Ester Suassuna Simões ${ }^{1}$}

Resumo: Em 1980 e 1985 Ariano Suassuna publicou Dez Sonetos Com Mote Alheio e Sonetos de Albano Cervonegro, álbuns com dez iluminogravuras, produções que integram poema e ilustrações criados pelo artista em consonância com o que propunha o Movimento Armorial: a realização de uma arte erudita a partir de elementos da cultura popular brasileira privilegiando a integração entre as diversas manifestações artísticas. Este trabalho apresenta essa produção de Suassuna e discute sua inserção no Movimento Armorial. Além disso, propõe-se, como amostra, uma leitura intersemiótica de duas dessas iluminogravuras, a saber: "O Sol de Deus" e "Abertura: 'sob pele de ovelha”".

Palavras-chave: Ariano Suassuna. Iluminogravura. Movimento Armorial. Intersemiose.

Abstract: In 1980 and 1985 Ariano Suassuna published his iluminogravuras in albuns entitled Dez Sonetos Com Mote Alheio (Ten sonnets with quotes from others) and Sonetos de Albano Cervonegro (Albano Cervonegro's sonnets). They integrate poetry and illustration in line with what proposed the Armorial Movement: the creation of high art based upon elements of Brazilian popular culture also favouring the integration between the various artistic manifestations. This paper presents those works by Suassuna and discusses their place in the Armorial Movement. As a sample, two iluminogravuras were also analysed: "O Sol de Deus" and "Abertura: 'sob pele de ovelha”".

Keywords: Ariano Suassuna. Iluminogravura. Armorial Movement. Intersemiosis.

Resumé: En 1980 et 1985, Ariano Suassuna a publié ses iluminogravuras dans les albuns intitulés Dez Sonetos com Mote Alheio (dix sonnets avec des citations d'autrui) et Sonetos de Albano Cervonegro (sonnets d'Albano Cervonegro). Ils intègrent la poésie et l'illustration en fonction de ce qui a proposé le Mouvement Armorial: la création d'art érudit basée sur des éléments de la culture populaire brésilienne favorisant également l'intégration entre les diverses manifestations artistiques. Cet article présente ces travaux de Suassuna et discute de leur place dans

\footnotetext{
${ }^{1}$ Mestrado em Teoria da Literatura (2016), pelo Programa de Pós-Graduação em Letras (PPGL), da Universidade Federal de Pernambuco (UFPE), atualmente é doutoranda do Programa de PósGraduação em Ciência da Literatura da Universidade Federal do Rio de Janeiro (UFRJ).
}

Este artigo está licenciado sob forma de uma licença Creative Commons Atribuição 4.0 Internacional, que permite uso irrestrito, distribuição e reprodução em qualquer meio, desde que a publicação 
le Mouvement Armorial. À titre d'exemple, deux iluminogravuras ont également été analysées: "O Sol de Deus" et "Abertura: 'sob pele de ovelha”.

Mots-clés: Ariano Suassuna. Iluminogravura. Mouvement Armorial. Intersemiosis.

\section{Introdução}

O oitavo dos nove filhos de Rita de Cássia e João Suassuna, Ariano, nasceu na capital do estado da Paraíba em 16 de junho de 1927. Quando o menino tinha apenas três anos de idade, sua família perde o convívio do pai, assassinado como consequência dos conflitos no âmbito da Revolução de 1930. Essa morte prematura marca profundamente Ariano Suassuna e toda a sua obra, que se constrói, de certa maneira, como uma homenagem à memória da figura paterna, como uma busca da recuperação do trauma pelo viés da arte.

A partir de 1930, Dona Ritinha, a viúva de João Suassuna, e seus filhos passam a ser perseguidos, tendo que mudar constantemente de casa e de cidade até conseguirem, finalmente, estabelecer-se em Taperoá (PB). É nessa vila sertaneja que Ariano conhece os espetáculos de circo e de mamulengo e também as apresentações de cantadores, as músicas e versos do romanceiro popular, manifestações que mais tarde seriam enormemente significativas em sua produção artística.

Em 18 de outubro de 1970, no Recife, é lançado oficialmente o Movimento Armorial. O princípio norteador desse movimento, que foi idealizado por Suassuna, é a busca pela realização de uma arte erudita brasileira a partir de elementos da nossa cultura popular. Entre os artistas do movimento, houve uma identificação mútua nessa busca, mesmo que a partir dela os caminhos traçados tenham sido vários. Essa 
identificação se deu também na tentativa de promover o diálogo entre as diferentes manifestações artísticas.

Grandes representantes desse projeto na obra de Suassuna são as suas iluminogravuras. Foram publicados dois álbuns com essa produção, cada um com dez sonetos escritos e ilustrados em matriz pelo próprio poeta em folhas de papel cartão: Dez Sonetos com Mote Alheio (1980) e Sonetos de Albano Cervonegro (1985).

É evidente que qualquer trabalho sobre este tema deve passar pela apreciação do diálogo entre a literatura e as outras artes, neste caso, especialmente a pintura. Sem essa consciência integradora da intersemiose, a leitura das iluminogravuras seria incompleta. Assim, este trabalho propõe duas tarefas complementares: uma apresentação geral das iluminogravuras e de sua inserção no Movimento Armorial; e uma sugestão de leitura intersemiótica de dois exemplares dessa produção de Suassuna.

Nas iluminogravuras, há uma primeira síntese do universo artístico suassuniano, inclusive no que ele representa de concretização do projeto armorial: criação de uma arte erudita brasileira a partir de raízes da cultura popular e da união de modalidades artísticas diferentes. Nesta perspectiva de integração, propusemos uma leitura das iluminogravuras a partir das representações simbólicas associadas a três eixos temáticos: a morte, o feminino e o sagrado.

\section{Iluminogravuras: definição e inserção no Movimento}

\section{Armorial}


As iluminogravuras de Ariano Suassuna sintetizam, como sugere o neologismo que as nomeia, pelo menos duas influências importantes: as iluminuras medievais e as gravuras populares do Nordeste brasileiro. Trabalho feito em papel cartão, cada iluminogravura contém um soneto e suas ilustrações que, criadas originalmente numa matriz com tinta nanquim (a exemplo do texto), foram em seguida copiadas em offset para, então, serem coloridas a mão por Suassuna.

Essa produção, que alia, portanto, a literatura às artes visuais, está, a nosso ver, totalmente inserida na estética do movimento artístico idealizado por Suassuna, o Movimento Armorial. Para explicar esta inserção, trataremos inicialmente do próprio movimento, suas origens e seus desdobramentos.

A palavra "armorial" é um substantivo da língua portuguesa ligado à Heráldica que designa o conjunto de brasões de um povo; seu uso como adjetivo também é um neologismo e começou a ser usado por Ariano Suassuna ainda na década de 1950 em títulos e versos de poemas seus (o poema "Canto Armorial", escrito em 1950, é um exemplo). Foi este neologismo que o escritor escolheu para nomear, posteriormente, o movimento artístico que idealizou e do qual permanece sendo o maior representante (NEWTON JÚNIOR, 1999, p. 90). Suassuna assim justifica a escolha desse nome:

Em nosso idioma, "armorial" é somente substantivo. Passei a empregá-lo também como adjetivo. Primeiro, porque é um belo nome. Depois, porque é ligado aos esmaltes da Heráldica, limpos, nítidos, pintados sobre metal ou, por outro lado, esculpidos em pedra, com animais fabulosos, cercados por folhagens, sóis, luas e estrelas. Foi aí que, meio sério, meio brincando, comecei a dizer que tal poema ou tal estandarte de Cavalhada era "armorial", isto é, brilhava em esmaltes puros, festivos, nítidos, metálicos e coloridos, como uma bandeira, 
um brasão ou um toque de clarim. Lembrei-me, aí, também, das pedras armoriais dos portões e frontadas do Barroco brasileiro, e passei a estender o nome à Escultura com a qual eu sonhava para o Nordeste. Descobri que o nome "armorial" servia, ainda, para qualificar os "cantares" do Romanceiro, os toques de viola e rabeca dos Cantadores - toques ásperos, arcaicos, acerados como gumes de faca-de-ponta, lembrando o clavicórdio e a viola-de-arco da nossa Música barroca do século XVIII (SUASSUNA, 1974b, p. 9).

É significativa, no trecho transcrito, a referência específica à arte na pedra, ao Barroco brasileiro e ao Romanceiro nordestino, pois Suassuna costumava identificar três elementos formadores da cultura brasileira: a arte rupestre, a arte barroca e a arte popular. Ao explicar o uso da palavra armorial, portanto, o escritor inscreve-a nestes três elementos fundadores e associa o seu projeto de obra artística à totalidade da cultura brasileira.

O Movimento Armorial foi lançado no Recife em 18 de outubro de 1970 com um concerto da Orquestra Armorial de Câmara e uma exposição de esculturas, pinturas e gravuras. Naquele momento, Ariano Suassuna era diretor do Departamento de Extensão Cultural (DEC) da UFPE, que promoveu o evento. Além do programa da exposição, que pode ser visto como um pequeno manifesto, não houve, para este movimento artístico, a produção de um texto mais extenso que comentasse a proposta geral de seus artistas. Assim, a divulgação inicial das ideias do Armorial foi feita posteriormente, por exemplo, através de entrevistas e palestras que o próprio Suassuna fez em vários lugares do país e em uma coluna intitulada "Almanaque Armorial", que o escritor assinou no Jornal da Semana por dois anos (1972-1974). Somente alguns anos depois do lançamento oficial é que o escritor então publica certos 
encaminhamentos e definições mais detalhados do Armorial. A definição geral do Movimento, publicada em 1974, assim explica:

\begin{abstract}
a Arte Armorial Brasileira é aquela que tem como traço comum principal a ligação com o espírito mágico dos "folhetos" do Romanceiro Popular do Nordeste (Literatura de Cordel), com a música de viola, rabeca ou pífano que acompanha seus "cantares", e com a Xilogravura que ilustra suas capas, assim como com o espírito e a forma das Artes e espetáculos populares com esse mesmo Romanceiro relacionados." (SUASSUNA, 1974b, p. 7).
\end{abstract}

Em linhas gerais, é possível afirmar que esse movimento aproximou artistas que tinham em comum a busca por uma arte erudita brasileira baseada nos elementos da cultura popular nordestina, mais especificamente, do folheto de cordel. É interessante a escolha dessa produção como fonte primeira: "Além do texto, oral ou escrito, a literatura de folheto oferece um modelo de integração de formas artísticas que a cultura erudita costuma distinguir com cuidado: palavra e imagem estão em contato direto" (SANTOS, 2009, p. 19). É possível perceber, então, que além das bases da cultura popular, outro princípio norteador importante do Movimento Armorial é a integração entre as artes. Não por acaso, estavam inseridos no grupo de armoriais artistas da música, das artes plásticas e da literatura e havia, desde o começo, um incentivo à união de produções de linguagens artísticas diversas.

Ainda como estudante da Faculdade de Direito do Recife, Suassuna conheceu Hermilo Borba Filho e José Laurênio de Melo, entre outros jovens artistas, com quem retomou o Teatro do Estudante de Pernambuco (TEP) em 1946. Foi no contexto do TEP que começaram as primeiras "experiências" de Suassuna na união entre o erudito e o popular no texto teatral, principalmente pela influência de Garcia Lorca, 
cuja obra Suassuna conheceu através de indicação do próprio Hermilo. Já nesse momento, portanto, as peças de Suassuna retomavam folhetos de cordel e entremezes de autoria popular e também seus poemas apresentavam essa tendência.Outra experiência formadora que pode ser citada, no campo da produção plástica, é a vivência de Suassuna como membro d'O Gráfico Amador, assim definido no primeiro boletim do grupo:

o Gráfico Amador reúne um grupo de pessoas interessadas na arte do livro. Fundado em maio de 1954, tem a finalidade de editar, sob cuidadosa forma gráfica, textos literários cuja extensão não ultrapasse as limitações de uma oficina de amadores. Os trabalhos são idealizados e projetados por Aloisio Magalhães, Gastão de Holanda, José Laurenio de Melo e Orlando da Costa Ferreira (LIMA, 2014, p. 53).

Assim, toda essa produção artística de Suassuna, já integrada com os princípios que posteriormente seriam defendidos no contexto do movimento, permite que se fale de uma fase embrionária, de pesquisa, ou preparatória do Movimento Armorial, que iria desde 1946 até 1969.

Os primeiros cinco anos que se seguiram ao lançamento oficial do movimento foram denominados por Suassuna de "Fase Experimental", seguida de uma segunda fase mais amadurecida, que chamou de Romançal:

Suassuna indica, como início da fase "romançal", o dia 18 de dezembro de 1975, quando a Orquestra Romançal Brasileira foi apresentada pela primeira vez ao público pernambucano, no Teatro Santa Isabel. A nova fase corresponde também a um novo ponto de apoio estratégico: em março de 1975, Suassuna tornou-se o Secretário de Educação e Cultura do Município de Recife [...] (SANTOS, 2009, p.29). 
Depois disso, por volta de 1980, há quem anuncie o fim do movimento. É o caso da própria Idelette dos Santos, que, após considerar que é difícil definir o final de um movimento artístico, afirma que se pode "arriscar a data de 1981 como o fim do movimento, quando Ariano Suassuna, numa carta aberta publicada no Diário de Pernambuco (DP), declara abandonar a literatura, deixar de publicar, de dar entrevistas, em suma, retira-se do palco cultural para realizar um balanço pessoal" (SANTOS, 2009, p. 32).

Em entrevista para o Jornal da BEP, em Porto de Galinhas em setembro de 2011, Ariano Suassuna diz que o Movimento Armorial continuava vivo e atuante. Em seguida, faz uma ressalva: "O mais importante é a presença de uma estética armorial. O Movimento mesmo, eu marco o tempo dele entre 1970 e 1980". A escolha do período tem a ver com um projeto maior em relação à sua produção artística e ao que a ela Suassuna pretendia associar. A Escola do Recife, importante movimento do século XIX que influenciou Suassuna, tem suas datas de atuação entre 1870 e 1880 . De propósito e como uma homenagem, portanto, Suassuna situa o Armorial precisamente um século depois.

Santos corrobora essa ideia de continuidade da estética armorial, ressaltando mais adiante no mesmo livro: "O movimento, enquanto fenômeno cultural necessariamente delimitado no tempo e no espaço, acabou, mas o Armorial permanece e constitui hoje uma das grandes correntes da nova geração de artistas brasileiros, principalmente no campo das artes plásticas, da música e do teatro" (SANTOS, 2009, p.282).

Essa continuidade seria marcada, para alguns autores, depois da Fase Romançal, por um momento de aprofundamento das questões levantadas nos anos anteriores e de renovação do Movimento com a 
chegada de novos artistas (Dantas Suassuna e Romero de Andrade Lima na pintura e o Trio Romançal na música, por exemplo). Newton Júnior (2011a, p. 4o) assim se posiciona sobre essa questão:

com o lançamento, em 1995, do Projeto Cultural PernambucoBrasil, elaborado por Suassuna para ser executado ao longo de sua gestão como Secretário Estadual de Cultura, no terceiro Governo de Miguel Arraes, inicia-se, a meu ver, a terceira fase do Movimento, que passei a chamar de Ilumiara e Suassuna chama de Arraial.

O período de "silêncio" de Suassuna citado por Santos durou quase dez anos. É, entretanto, um período de grande produção. Como exemplo, podemos dizer que datam de 1980 e 1985 as publicações do primeiro e do segundo álbuns de iluminogravuras, intitulados, respectivamente, Dez Sonetos com Mote Alheio e Sonetos de Albano Cervonegro. Esse gênero, como identifica Newton Júnior (1999, p. 123), "não deixa de ser uma resposta concreta a um dos sonhos do Movimento Armorial”. Ao dizer isso, o estudioso se refere, especificamente, à seguinte formulação feita por Suassuna:

O sonho de unir o texto literário e a imagem num só emblema, para que a Literatura, a Tapeçaria, a Gravura, a Cerâmica e a Escultura falem, todas, através de imagens concretas, firmes e brilhantes, verdadeiras insígnias das coisas. Insígnias de qualquer maneira desenhadas, gravadas e iluminadas - sobre superfícies de pedra, de barro-queimado, de tecido, de couro, de áspero papel ou, então, modeladas pela forma e pela imagem da palavra. (SUASSUNA, 1989, s/p).

Dezesseis dos vinte sonetos que foram iluminogravados faziam parte anteriormente de um livro chamado Vida Nova Brasileira. Como em Vida Nova, de Dante Alighieri, o texto desse livro é composto por intercalações de poesia e prosa. Os trechos em prosa apresentam os 
sonetos que seguem, fazendo referências a fatos da vida do autor que contextualizam o soneto e garantem a sequência narrativa entre eles, que formam, assim, uma autobiografia poética.

A existência deste texto anterior permite afirmar que, já em sua concepção, os sonetos iluminogravados formavam um conjunto que, na verdade, seguia uma linha narrativa. Se, em Vida Nova Brasileira, essa linha narrativa era entrelaçada pela prosa, nos álbuns iluminogravados, ela fica a cargo da própria ordenação dentro dos álbuns (caixas de madeira cuja capa também era ilustrada por Suassuna). No caso do primeiro álbum, há também uma espécie de roteiro de leitura, uma folha introdutória em que, de maneira sucinta, Suassuna apresenta o tema de cada uma das iluminogravuras.

O processo de confecção das iluminogravuras impôs, inicialmente, uma reduzida tiragem de apenas 50 exemplares: feitas as matrizes com tinta nanquim em papel cartão, estas eram copiadas através do processo offset e, em seguida, coloridas à mão. Suassuna contou, nesta segunda parte, com a ajuda da sua esposa, a artista plástica Zélia Suassuna e de sua filha, Maria Suassuna. Depois da tiragem inicial, durante décadas o escritor continuou a fazer iluminogravuras avulsas, de maneira que comumente se tem acesso a cópias isoladas de seu conjunto original, às vezes com datas diferentes de 1980 e 1985.

Embora de certa maneira raros, há caminhos de se acessar estes conjuntos em sua totalidade. Foram feitas algumas publicações em contextos diversos, catálogos, agendas, etc. Se o romance inédito seria uma síntese total de vários gêneros diferentes, as iluminogravuras podem ser consideradas o primeiro passo neste caminho. Nelas, unemse, em harmonia e ressignificação, literatura e artes plásticas a partir dos 
três elementos que Suassuna considerava fundadores da cultura brasileira: a arte rupestre, a arte barroca e a arte popular.

O texto literário, nas iluminogravuras, é o poema. De tal forma a produção poética de Suassuna é integrante do seu projeto de produção artística, que é impossível não a considerar quando do estudo de sua obra. Principalmente pelo que essa poesia representa de sucesso em relação ao que sempre postulou como princípios de seu fazer artístico:

a gramática da criação poética de Ariano consiste numa reorganização articulada dos elementos da cultura popular de modo a fazê-los reacender seu sentido de resistência à inevitabilidade despótica do real, à pressão do presente duro que sempre ameaça de desagregação as forças do sonho (HOLANDA, 2007, p. 98).

É verdade que, repletos de símbolos cujas referências se formam dentro do próprio texto, além de inversões e uso de léxico diferenciado, os poemas de Suassuna nem sempre são de fácil apreciação. Tornam-se de mais fácil acesso, porém, quando lidos em conjunto com outros poemas ou com peças e romances do autor.

Isto se dá pelo caráter sistêmico ${ }^{2}$ da produção do poeta, que criou - ou vinha criando em continuidade - um mesmo universo artístico e simbólico no qual convivem peças de teatro, romances, poesia, pintura, escultura e tapeçaria. Sobre isto, diz Newton Júnior (1999, p. 111): “o hermetismo, na poesia de Suassuna, não surge como uma opção gratuita do autor. Antes, é uma espécie de condenação ditada pela própria obra”.

É de assinalar também a linguagem visual da poesia de Suassuna, que, com léxico próprio e bem trabalhado, alude à fauna e à flora do

\footnotetext{
2 Expressão utilizada por Jarbas Maciel e retomada por Carlos Newton Júnior (1999, p. 16).
} 
sertão, mas também às bandeiras, cores e insígnias usadas pelo povo. A literatura armorial, em geral, parece prezar por essa visualidade. Esse aspecto da poesia de Ariano Suassuna pode ser visto como facilitador, nas iluminogravuras, da interação texto - imagem. Talvez tenha sido, então, buscando ampliar as possibilidades de expressão artística e, ao mesmo tempo, criar "chaves" de acesso aos poemas ditos herméticos que Suassuna selecionou 20 sonetos seus e, ilustrando-os, criou dois álbuns de iluminogravuras, gênero que, como estamos tentando demonstrar, conecta-se com as propostas do Movimento Armorial, tanto no que diz respeito às bases do folheto de cordel e da arte rupestre quanto à integração entre as artes. Parece-nos claro que as iluminogravuras são realmente os emblemas unificados de poesia e artes plásticas com que sonhou Suassuna no trecho anteriormente transcrito.

\section{Texto e imagem nas iluminogravuras}

Nas iluminogravuras de Suassuna, a relação intersemiótica que se estabelece mais fortemente é entre poesia e pintura. $O$ estudo comparativo entre essas duas modalidades não é novidade: Gonçalves (1994) explica que já na Antiguidade o assunto das artes comparadas foi de grande importância, e que os frutos das análises desse período foram retomados nos séculos XVI, XVII e XVIII, estando bastante presentes tanto nas produções artísticas quanto nas discussões críticas e filosóficas nesses séculos. Ainda segundo esse mesmo autor, no início do século XVIII, pensadores e artistas evocaram textos gregos e latinos - o ut pictura poesis de Horácio e a frase "a pintura é uma poesia muda; a 
poesia, uma pintura que fala" de Simônides de Ceos, por exemplo - para defender uma forte união e influência criadora entre os dois gêneros.

Em 1766, G. E. Lessing muda o rumo das discussões sobre o tema com a publicação do seu trabalho Laocoonte ou sobre as fronteiras da pintura e da poesia, estabelecendo, como o título sugere, fronteiras claras entre os dois gêneros. O autor destaca, em sua argumentação, que a pintura (termo que utiliza como sinônimo de artes plásticas) e a poesia utilizam meios ou signos bastante diferentes: a pintura utiliza figuras e cores no espaço; a poesia utiliza sons articulados no tempo. Ele separa, então, as artes em temporais e espaciais, cabendo às primeiras a expressão de ações e às últimas a expressão de corpos.

Ainda segundo o autor, as artes espaciais são essencialmente estáticas, não sendo ideais para a narrativa. No caso das artes temporais, a dinâmica e a progressão que lhes são possíveis demandam, no caso de se fazer descrições, que essas sejam feitas através de ações das personagens. Pode-se sintetizar a postulação de Lessing da seguinte maneira:

a forma, nas artes plásticas, é espacial, pois o aspecto visível dos objetos pode ser mais bem apresentado justaposto, num lampejo de tempo; a literatura, por outro lado, fazendo uso da linguagem, para harmonizar-se com a característica essencial de seu instrumento, deve se basear em alguma forma de narrativa (GONÇALVES, 1994, p. 89-90).

Sobre o caráter temporal da poesia, Octávio Paz (1996, p.54) diz que o que torna o poema único e "o separa do resto das obras humanas é o seu transmutar o tempo sem abstraí-lo; e essa mesma operação levao, para cumprir-se plenamente, a regressar ao tempo". 
Em sua análise, Lessing posiciona a poesia como hierarquicamente superior à pintura. No caso das iluminogravuras, não pretendemos apontar superioridade de nenhuma das duas modalidades. Suassuna afirmou repetidas vezes que seu desenho é fruto da sua poesia, e não o inverso. Apontar superioridade do texto, no entanto, seria, na nossa opinião, desconsiderar a integração existente entre texto e imagem nas iluminogravuras.

Propomos uma "leitura intersemiótica", que, mesmo levando em conta os pressupostos teóricos aqui discutidos, não perca de vista o seu caráter de leitura, ou de tentativa inicial de interpretação que considere tanto as imagens poéticas quanto as imagens pictóricas envolvidas. Sobre isso, Umberto Eco diz que todo texto "está entremeado de espaços brancos, de interstícios a serem preenchidos" (ECO, 2012, p. 37) e que "a noção de interpretação sempre envolve uma dialética entre estratégia do autor e resposta do Leitor-Modelo" (ECO, 2012, p. 43). No caso específico da poesia, o leitor se depara com imagens poéticas, que, de acordo com Octávio Paz (1996, p. 37), podem ser definidas como "toda forma verbal, frase ou conjunto de frases que o poeta diz e que unidas compõem uma referência poética”. Segundo o autor, é a imagem que garante que o verso - uma frase rítmica - seja também frase com sentido.

Ainda de acordo com Paz (1996), qualquer idioma constitui-se em uma infinita possibilidade de significados. Quando transformada em frase, verdadeiramente em linguagem, essa possibilidade tende a fixar-se em uma única direção. No entanto, "a imagem é uma frase em que a pluralidade de significados não desaparece. A imagem recolhe e exalta todos os valores das palavras, sem excluir os significados primários e secundários" (PAZ, 1996, p. 45). 
Referindo-se a imagens pictóricas, Manguel (2009, p.27) diz que quando lemos imagens "ampliamos o que é limitado por uma moldura para um antes e um depois e (...) conferimos à imagem imutável uma vida infinita e inesgotável". O objeto artístico não deve, no entanto, ser visto como receptáculo passivo das interpretações do leitor, pois "são os olhos leitores que colocam a obra em movimento, numa troca constante de papéis de sujeitos da ação, na medida em que, em determinado momento, é a obra de arte que atua como sujeito do processo de leitura" (BUORO, 2003, p. 43).

Baseando-se em estudos da psicologia cognitiva, Varga (1999) diz que a ideia de se comparar texto e imagem, do ponto de vista da recepção, não é, como pode parecer à primeira vista, um movimento de comparação de duas atividades radicalmente diferentes. Ao estudar obras onde palavra e imagem partilham um espaço comum, o autor propõe, então, dar prioridade às coincidências que unem os dois sistemas. Pragmaticamente, fala de três tipos de coincidência: a coincidência parcial, que acontece quando parte do texto pode ser separada do resto na medida em que constitui, também, uma imagem (o autor complementa que a imagem não existe para decorar, mas para dar ao leitor uma segunda possibilidade de leitura); a coincidência total, caso em que texto e imagem são completamente inseparáveis, a saber, o poema figurativo, o poema visual e a pintura textual; a coincidência escondida, caso em que textos literários são produzidos a partir de imagens, no fenômeno ekphrasis.

Hoek (2006) faz sua reflexão sobre obras que integram texto e imagem a partir de duas perspectivas: a da recepção e a da produção. Do ponto de vista da produção é preciso notar que, enquanto o observador 
percebe imagem e texto como simultâneos, o artista, por outro lado, faz uma escolha a partir de um critério de sucessão. Seguindo esse critério, Hoek (2006) propõe, então, três classificações. A primeira, quando a imagem precede o texto. A segunda, quando o texto precede a imagem, gerando uma relação multimedial (em uma única obra) ou transmedial (duas obras diferentes). Por fim, quando há simultaneidade - texto e imagem perdem a auto-suficiência criando, a depender da relação física existente, um discurso misto ou sincrético.

O texto das iluminogravuras precede suas ilustrações e não há, em geral, presença de ekphrasis. Única exceção talvez seja na obra "O Mundo do Sertão", em que há referências que sugerem a construção do soneto a partir do brasão da família Suassuna, criado por Ariano. Podemos falar, portanto, em relação multimedial intensificada pelo fato de poeta e ilustrador serem a mesma pessoa. Essa relação se fortalece também, a nosso ver, pela coesão simbólica que permeia essa produção. Essa já discutida recorrência simbólica, característica da produção de Suassuna, é significativa tanto no âmbito pictórico quanto no âmbito lexical da iluminogravuras e mostra-nos que o caráter "sistêmico" do trabalho do escritor demanda que qualquer estudo sobre uma de suas partes seja feito com uma certa visão da totalidade. A construção dessa enorme obra de arte completa passa por sua produção, como já dito, em prosa, verso, pintura. Mas também em tapeçaria, por exemplo, e nas grandes esculturas que foram feitas por Arnaldo Barbosa para compor a Ilumiara Pedra do Reino, espaço idealizado por Suassuna em São José do Belmonte, PE. Podemos, inclusive, dizer que a própria vida do escritor fazia parte deste projeto: suas aulas-espetáculo, a maneira como fez e decorou sua casa, sua maneira de se vestir, os apelidos que dava aos mais 
próximos. Tudo isso fazia parte de um universo coeso e, portanto, mais acessível quando apreciado em conjunto.

No universo artístico uno de Suassuna inserem-se símbolos e alegorias próprias. A romã como representação do feminino é um exemplo, bem como a imagem de Caetana, alegoria original criada a partir do nome dado pelos sertanejos para a morte. Há um léxico característico deste universo, com grande incidência de termos como, por exemplo, Sangue, Pedra, Sol, Sertão, Mundo e Morte em toda a poesia do escritor, bem como em seus textos de teatro e de prosa.

Parte importante para a compreensão desses símbolos recorrentes talvez seja reconhecer o diálogo que há entre eles e obras que os precederam. Suassuna é um escritor que nunca se preocupou em esconder as influências que recebeu para construir sua obra. Pelo contrário, declarava-as frequentemente em entrevistas e aulas. Nelas, costumava citar, por exemplo, Cervantes, Euclydes da Cunha e Mathias Ayres. Nas iluminogravuras, percebe-se que a relação entre texto e imagem vem também dessas muitas fontes inspiradoras.

Em entrevista concedida por ocasião de uma exposição de suas iluminogravuras, Suassuna citou como inspiração para este seu trabalho, na "tradição da arte medieval, as chamadas iluminuras, que eram obras feitas normalmente nos mosteiros e conventos, por frades, muitas delas tendo como assunto o Apocalipse" (SUASSUNA, 2008b, s/p). Podemos apontar como características comuns às iluminuras medievais, especialmente aquelas de cenas do apocalipse, e às iluminogravuras de Suassuna: o repertório de imagens fantásticas, inclusive de animais e bestas; recorrência do uso de cores primárias, principalmente no primeiro álbum; demarcação de espaços com molduras; cenas estáticas 
voltadas para o observador; trabalho especial de caligrafia nos títulos e nas primeiras letras dos textos.

Nas iluminogravuras, o trabalho de caligrafia tem duas fontes primordiais. A primeira, seriam os ferros de marcar gado, tradição sertaneja que Suassuna associa à arte heráldica europeia:

a unidade nacional brasileira vem do Povo, e a Heráldica popular brasileira está presente, nele, desde os ferros de marcar bois e os autos dos Guerreiros do Sertão, até as bandeiras das Cavalhadas e cores azuis e vermelhas dos Pastoris da Zona da Mata. Desde os estandartes de Maracatus e Caboclinhos, até as Escolas de Samba, as camisas e as bandeiras dos Clubes de futebol do Recife ou do Rio (SUASSUNA, 1977b, p. 4o).

A partir dos ferros, Suassuna criou o alfabeto sertanejo, publicado no livro Ferros do Cariri: uma heráldica sertaneja (1974). É com esse alfabeto que ele escreve alguns dos títulos de iluminogravuras, e também as letras iniciais de alguns sonetos. Outra fonte para a caligrafia nesses trabalhos é a arte rupestre, que, principalmente depois da primeira fase do movimento, aparece como grande influência nas produções armoriais. As imagens, por exemplo, da itaquatiara Pedra do ingá, na Paraíba, aparecem em várias iluminogravuras, e alguns dos títulos de sonetos recebem uma caligrafia que lembra os traços de suas insculturas.

As ilustrações das iluminogravuras foram feitas à mão por Suassuna, mas a presença das xilogravuras populares é clara tanto no traço quanto nos temas. Há, portanto, um respeito às características da produção, por exemplo, de J. Borges, sendo possível afirmar o parentesco das ilustrações do Romance d'A Pedra do Reino e das iluminogravuras com a xilogravura popular: "parentesco que reside na ausência de perspectiva, na despreocupação em relação à anatomia, nos desenhos 
chapados, nos traços toscos e fortes, na profundidade e relevos apenas indicados, enfim, na intenção de se afastar de uma representação ideal do real" (NEWTON JÚNIOR, 1999, p.133) .

\section{Do álbum Dez Sonetos com Mote Alheio (1980), a iluminogravura “O Sol de Deus”}

No primeiro dos álbuns de iluminogravuras, há, em geral, uma relação mais direta entre texto e ilustração. Isso não é verdade para todas as imagens presentes no álbum, mas há uma frequência significativa dessas correspondências em todas as dez iluminogravuras que o compõem. Outra característica geral deste primeiro conjunto é o uso constante de fundo branco sobre o qual se apresentam o texto e as imagens. Na viagem que aqui começamos, pouca é a variedade de cores: excetuando-se a pequena área verde na bandeira da figura do canto inferior direito da primeira iluminogravura, as únicas cores utilizadas nas dez obras deste álbum são: preto, marrom, azul, amarelo e vermelho.

Mais uma singularidade desse primeiro conjunto é a presença de molduras delimitadoras, que parecem, aliadas ao uso do fundo branco, marcar um maior parentesco entre as iluminogravuras do primeiro álbum com as iluminuras medievais. Além da aproximação com as iluminuras, a pouca variedade de cores comentada no parágrafo anterior também faz transparecer o parentesco com a arte heráldica, que aceitava, tradicionalmente, apenas o uso de cinco variedades de esmaltes.

O título do primeiro álbum de iluminogravuras (Dez Sonetos com Mote Alheio) faz referência a um recurso bastante comum na poesia popular nordestina: o uso de motes e temas de textos de outros autores, 
ou fornecidos na hora, pelo público, no caso de poesias de improviso. A retomada de textos de outros autores é bem comum na obra de Suassuna. Os dez sonetos do primeiro álbum são escritos, portanto, a partir de versos usados tal qual em poemas anteriores (motes) ou ligeiramente modificados (temas), como no exemplo a seguir. Em "Poema Negro", de Augusto dos Anjos (2001, p. 106), lemos: “A Morte, em trajes pretos e amarelos, / Levanta contra mim grandes cutelos / E as baionetas dos dragões antigos."; no soneto iluminogravado "O Amor e a Morte" (SUASSUNA, 1980), lemos: "E a Morte, em trajos pretos e amarelos, / Brandirá, contra nós, doidos Cutelos / e as Asas negras dos Dragões antigos".

A relação de herança reverenciada nos motes é a de uma tradição ocidental, mas a que marca a sua obra com maior força é aquela proveniente de seu pai. Tudo que escreve é endereçado a este pai ausente. Ao Pai com letra maiúscula de seus poemas. As questões de luto, herança e endereçamento são, portanto, centrais em sua produção.

Para Derrida (2004, p.12), a posição do herdeiro é complexa e inclui uma dupla injunção, dois movimentos de certa forma contraditórios. $\mathrm{O}$ primeiro é involuntário e anterior mesmo ao nascimento: recebe-se uma herança antes mesmo de saber-se. A segunda vem do caminho da aceitação e pode ser uma reafirmação feita enquanto sujeito livre. Seria o movimento de "não apenas aceitar essa herança, mas relançá-la de outra maneira e mantê-la viva. Não escolhê-la (pois o que caracteriza a herança é primeiramente que não é escolhida, sendo ela que nos elege violentamente), mas escolher preservá-la viva” (DERRIDA, 2004, p. 12).

Ao prolongar o luto do pai até o momento de sua própria morte, Suassuna lamentava aquele homem que ele mesmo poderia ter sido, caso 
tivesse tido a oportunidade de conviver com seu cavaleiro encantado. Com a morte de um ente querido, aquele "eu" que ama e que é amado, vai embora também. Se a morte do pai ou da mãe acontece antes que tenhamos consciência de quem somos, o luto é por uma parte de nós ainda em potencial. Há de se procurar a resposta, talvez, na própria veia. Há de se buscar o sangue, sua origem e sua permanência.

No primeiro álbum de iluminogravuras, o leitor acompanha um caminho tortuoso pelo caos que se estabelece a partir da morte do pai. É no décimo trabalho deste álbum que Suassuna configura pela última vez, em Dez Sonetos com Mote Alheio, o sentido da morte. Essa morte, que já havia sido mostrada, nos sonetos anteriores, como um trauma do passado, como o castigo que trará o fim da vida no futuro, como a mulher que assusta e seduz no presente, agora, em "O Sol de Deus", aparece iluminada por outro sentido: 
Figura 1 - "O Sol de Deus"

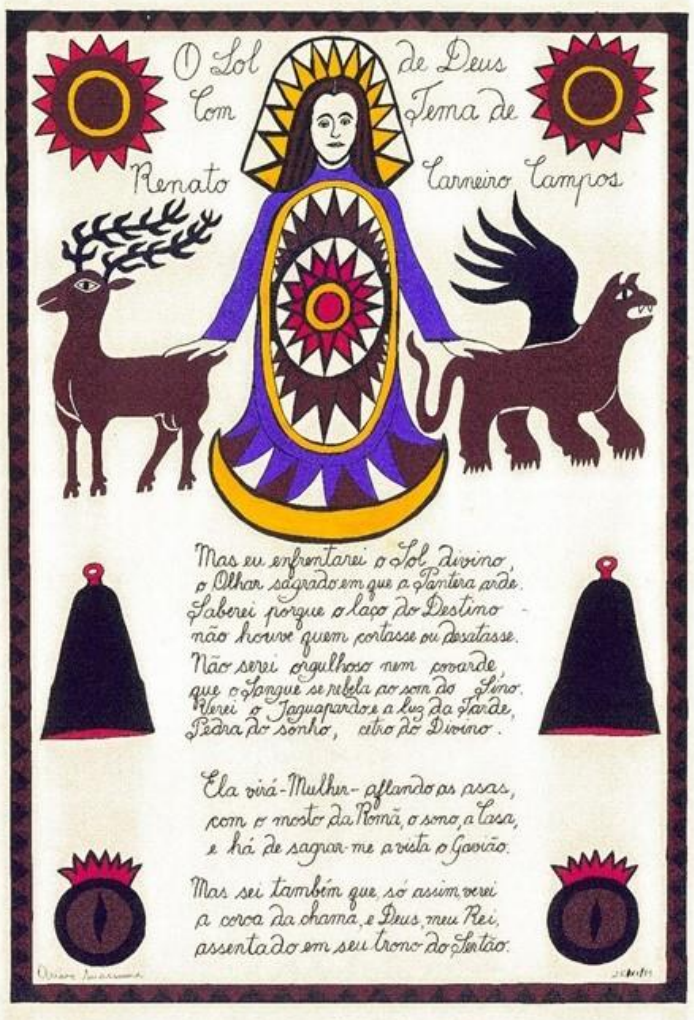

O Sol de Deus

Com Tema de Renato Carneiro Campos

Mas eu enfrentarei o Sol divino, o Olhar sagrado em que a Pantera arde. Saberei porque o laço do Destino não houve quem cortasse ou desatasse.

Não serei orgulhoso nem covarde, que o Sangue se rebela ao som do Sino. Verei o Jaguapardo e a luz da Tarde, Pedra do sonho, cetro do Divino.

Ela virá - Mulher - aflando as asas, com o mosto da Romã, o sono, a Casa, e há de sagrar-me a vista o Gavião.

Mas sei também que, só assim, verei a coroa da chama, e Deus, meu Rei, assentado em seu trono do Sertão.

Fonte: SUASSUNA, 1980.

A ressignificação da morte no álbum faz-se completa nesse soneto final. $\mathrm{O}$ primeiro verso inicia-se com a conjunção adversativa "mas", que permite duas interpretações. A primeira delas é uma reação de enfrentamento diante da visão da Moça Caetana, cantada no soneto anterior. Essa mulher que virá (no futuro, a morte não é mais trauma passado) é a própria Caetana, provavelmente em sua forma de onça alada, já fundida com suas cobras e gaviões, um deles responsável por "sagrar" sua vítima. A segunda das interpretações é a negação de todas as ideias de morte e de vida que antecederam a que o poeta agora canta: a morte como uma batalha, uma passagem que permite a redenção, o encontro com o divino. 
Essa presença divina, que, ao final, justifica a existência humana e que é, também, feminina: na alusão a Caetana, na terceira estrofe do soneto; na imagem das romãs, símbolo do sexo feminino; na figura central da iluminogravura, à qual não há referência direta no soneto, mas que, no plano pictórico, acolhe e protege as figuras animais que podem ser vistas como representações do próprio poeta (o cervo negro, significado do nome "Suassuna") e da morte (Onça Caetana).

A figura feminina veste roupa de cor azul, como o manto de Nossa Senhora, mas a sua representação aproxima-a muito mais fortemente de outra figura bíblica, presente no livro do Apocalipse, citado neste trabalho como uma das fontes de inspiração das iluminogravuras: "e viu-se um grande sinal no céu: uma mulher vestida do sol, tendo a lua debaixo dos seus pés, e uma coroa de doze estrelas sobre a sua cabeça” (Apocalipse 12:1). A mulher vestida de sol (título, inclusive, de uma peça escrita por Suassuna) foi tema de várias iluminuras medievais e aqui representa a face feminina de Deus.

Além da Virgem Maria e da Mulher Vestida de Sol, Suassuna (2015) via a face materna de Deus em uma figura do antigo testamento, a Sabedoria (Santa Sofia, a santa sabedoria de Deus³). No soneto que termina o álbum, os verbos são conjugados no futuro e a morte de que se fala é a do próprio poeta. E ele agora entende que a santa sabedoria só poderá ser acessada completamente no momento em que findar a vida terrena. Não há mais cegueira, nem caos: o poeta sabe o que o aguarda e anseia pelo momento em que, fortalecido, iluminado por esse

${ }^{3}$ Ver comentário sobre a Sabedoria mais adiante neste trabalho. 
sol divino e pelo toque da romã, poderá avistar Deus e cumprir sua passagem.

"Sol" é uma palavra recorrente nos sonetos iluminogravados e também na obra de Suassuna em geral. Como símbolo, ele é, em geral, bastante associado ao masculino, principalmente quando em oposição à lua, símbolo do feminino. No plano pictórico das iluminogravuras, também há muitas ocorrências de figuras do sol, duas, por exemplo, na iluminogravura que aqui analisamos. $O$ masculino na obra de Suassuna, principalmente nos primeiros poemas iluminogravados, é bastante ligado à figura do seu pai, pela permanente ausência-presença que ela representa. Essa ligação também se faz representada na imagem do sol.

Além da figura do pai, o sol masculino por vezes representa o próprio corpo do homem, seu sexo: "Abres ao sol tua Romã felina”, reforçando essa ideia de símbolo masculino. Porém, ao observar as ocorrências dessa palavra nos sonetos dos dois álbuns estudados, percebemos algo que não antecipávamos: o sol, símbolo do masculino, muitas vezes aparece associado a uma imagem de representação da morte, que, na obra de Suassuna, é mais comumente apresentada como uma entidade feminina. No primeiro álbum, isso acontece como neste último soneto, o sol como destino final e também ligado às definições do destino.

Em Dez Sonetos com Mote Alheio, o tema da morte, que começa como o trauma que condena o poeta a uma vivência trágica do mundo, transforma-se, ao final, em encontro terrível e maravilhoso com o sagrado, a busca maior do caminho humano. Essa reconstrução - da 
marca traumática no passado ao encontro futuro - é contínua. O sangue que fervia contra a vã razão e prometia pulsar o amor na escuridão no soneto "A Mulher e o Reino", se fortalece em "O Sol de Deus" e, assim, se rebela ao som do Sino, garantindo que o poeta não seja nem orgulhoso nem covarde diante da morte. O desespero e a confusão causados pela perda do Rei-pai em "A Acauhan - A Malhada da Onça”, os quais provocam o caos na vida do menino sem lei nem Rei de "Infância" e "A Estrada", são diluídos pela chegada da mulher, figura que permite a construção, ao longo dos sonetos do álbum, da figura de um novo Rei, Deus, que finalmente receberá o poeta assentado em seu trono do Sertão.

\section{Do álbum Sonetos de Albano Cervonegro, a iluminogravura "Abertura - 'sob pele de ovelha”"}

Preparado pela narrativa do primeiro álbum, o leitor inicia a leitura do segundo, em que novamente se destacam os elementos da morte, do feminino e do sagrado. Parece que essa trindade temática vibra em todo o conjunto das vinte iluminogravuras, mas é no segundo álbum que ela passa verdadeiramente a reger tudo como uma unidade. Os sonhos do poeta, sua visão e também os seus sentidos estão tomados por esse eixo central.

A "Abertura" desse segundo conjunto é como um portal. Passando por ele, adentra-se um mundo de sonho e de enigma que sintetiza muitas das questões levantadas ainda em Dez Sonetos com 
Mote Alheio, mas que, por outro lado, não segue a mesma linearidade narrativa.

Não por acaso, três dos quatro sonetos iluminogravados que não estão em Vida Nova Brasileira pertencem a este álbum. O fio condutor da narrativa, que em Vida Nova era feito pelo texto em prosa, em Sonetos de Albano Cervonegro não é fixo, acontece como em um sonho. Permanece, porém, ao final da leitura, a possibilidade de se identificar um ciclo que se fecha, inclusive com uma saída possível, um caminho apontado.

No título deste conjunto, Suassuna assume um pseudônimo, o que poderia sugerir um certo afastamento entre sua experiência pessoal e as chaves de leitura de seus sonetos. No entanto, ainda que diluídas em imagens enigmáticas de sonhos, nos poemas de Albano Cervonegro ainda há fortes referências à vida de Suassuna, a começar pelo próprio pseudônimo, formado, como já foi visto, a partir do nome do poeta.

Como claramente indicado em seu título, a iluminogravura "Abertura 'sob pele de ovelha” é a primeira do segundo álbum. Assim, como sugere ser a primeira de uma sequência, ela pode e, a nosso ver, deve - em concordância com o que pensamos ser o caráter sistêmico da produção de Suassuna - ser vista como integrante de um conjunto.

Além da palavra abertura, definidora do caráter de obra integrante de uma sequência, o título apresenta também a expressão "sob Pele de Ovelha", primeira referência bíblica do texto. Assim diz Jesus, na passagem Mateus 7:15: "Cuidado com os falsos profetas, que vêm até vós vestidos como ovelhas, mas, interiormente, são lobos devoradores". A partir da identificação da origem do título, o leitor está 
convidado a desconfiar do que vai ler e do que vê como imagem pictórica. Vemos este título como um alerta e como uma chamada para o desvendar dos diversos segredos e artimanhas escondidos atrás da "pele de ovelha" e do enigma que caracteriza o álbum.

Figura 2 - "Abertura 'sob pele de ovelha""

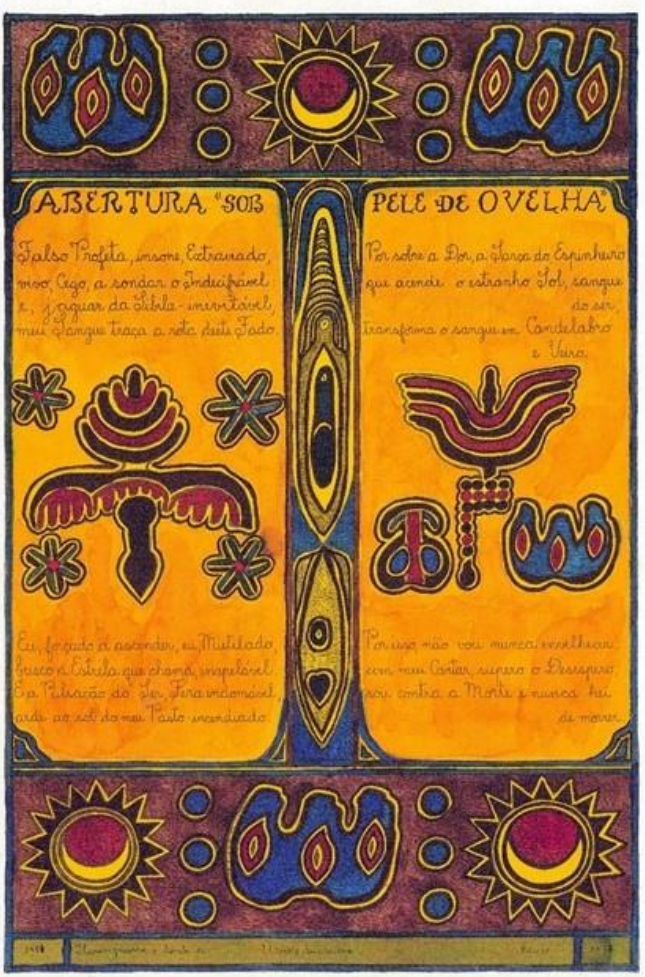
Abertura "sob pele de ovelha"
Falso Profeta, insone, Extraviado, vivo, Cego, a sondar o Indecifrável:
e, jaguar da Sibila-inevitável, meu Sangue traça a rota deste Fado.
$\mathrm{Eu}$, forçado a ascender, eu, Mutilado, busco a Estrela que chama, inapelável. E a Pulsação do Ser, Fera indomável, arde ao sol do meu Pasto-incendiado.
Por sobre a Dor, a Sarça do Espinheiro que acende o estranho Sol, sangue do ser, transforma o sangue em Candelabro e Veir
Por isso, não vou nunca envelhecer: com o meu Cantar, supero o Desespero, sou contra a Morte e nunca hei de morrer.

Fonte: SUASSUNA, 1985.

No âmbito da ilustração, se conhecemos Dez Sonetos com Mote Alheio, talvez a primeira coisa que notemos nesta iluminogravura seja o trabalho com a cor. No segundo conjunto de sonetos, a cor é muito mais vibrante e muito mais presente do que no primeiro. $O$ fundo branco, que aproxima o primeiro álbum aos manuscritos medievais, aqui quase não aparece.

Outra diferença entre os dois álbuns de Suassuna é a natureza das 
representações pictóricas. Há, em geral, menos representações diretamente ligadas ao texto nas iluminogravuras de Sonetos de Albano Cervonegro. Assim, neste primeiro trabalho, inicialmente percebem-se várias imagens, pintadas com as cores azul, amarelo, preto e vermelho, organizadas de forma simétrica e, entre elas, talvez somente os três sóis e algumas flores a esquerda sejam identificáveis em primeira instância.

Essa peculiaridade do segundo álbum é resultado da forte influência da arte pré-colonial brasileira, principalmente das insculturas da Pedra do Ingá. Como já foi dito, essas figuras suscitaram, ao longo do tempo, diversas interpretações diferentes, muitas vezes ligadas ao universo mítico. A voz de Suassuna se junta, portanto, ao coro dos que, fascinados com essa produção, atribuíram sentidos próprios ao que viam; o leitor das iluminogravuras está convidado a fazer o mesmo. Se é verdade que o receptor é parte ativa da construção de sentido de qualquer texto, nas ilustrações deste conjunto essa relação nos parece ainda mais marcante. As duas imagens maiores e centrais de "Abertura 'sob Pele de Ovelha"' são exemplos de releituras das imagens da itaquatiara do Ingá. Assim, "transcritas" e "reaproveitadas" pelo poeta, elas ganharam novos significados. Reconhecendo nessas formas semelhanças com o candelabro judaico, a menorá, Suassuna chamou-as de candelabro da Verdade (à esquerda) e candelabro da Beleza (à direita).

A relação dessas duas entidades com o texto do poema é próxima: a busca do poeta é por Verdade e Beleza, é esse o caminho que o liberta da morte e lhe serve de guia, ele que antes "cambaleava cego ao Sol do Acaso", como diz o verso de "Infância", soneto do primeiro álbum de 
iluminogravuras. No princípio, era o Verbo, e é por ele que há de se alcançar o divino, a imortalidade, a Verdade e a Beleza.

Todos os outros desenhos da iluminogravura são reproduções ou releituras de figuras da Pedra do Ingá. Os dois símbolos que ladeiam o candelabro da direita podem ser associados aos sexos masculino e feminino e também ligados ao sentido de origem e de princípio. É o caso, novamente, do sol e da lua integrados, que aparecem três vezes na iluminogravura. Em toda a ilustração - e essa é uma característica comum a várias iluminogravuras - é bem marcada a simetria na organização espacial e vários elementos aparecem três vezes.

O imaginário bíblico, evocado nas imagens do soneto e na referência ao candelabro judaico, pode ser lembrado aqui também na santíssima trindade, Pai, Filho e Espírito Santo. Mas a trindade não é um elemento exclusivo da cristandade, como exemplifica Campbell (1997, p. 102) citando outros autores:

Pico e Ficino reverenciavam essas três [as graças] como uma tríade arquetípica exemplar de todas as outras do mito clássico. Nas palavras de Pico: "Aquele que compreende profunda e claramente como a unidade de Vênus é desdobrada na trindade das Graças, a unidade da Necessidade na trindade das Parcas e a unidade de Saturno na trindade de Júpiter, Netuno e Plutão conhece a maneira adequada de proceder na teologia órfica”. Como salientou Edgar Wind comentando essa passagem, "era um axioma da teologia platônica que cada deus exerce o seu poder em um ritmo triádico".

Muitas são as referências a textos bíblicos neste soneto. Podemos falar, segundo as categorias de Genette (2010, p.14), em intertextualidade na sua forma menos explícita, a alusão. A voz do poeta se identifica logo no primeiro verso com o Falso Profeta, contra 
o qual alerta Jesus na passagem já comentada. O poeta vê mais do que o homem comum e busca a Beleza e a Verdade dos candelabros, mas não é Deus, e segue, por isso, falso profeta. E o caminho é árduo: por ele, o poeta segue insone, extraviado, cego, buscando decifrar o que é, para qualquer mortal, indecifrável.

O falso profeta em questão busca a Estrela Inapelável. Sobre essa estrela, diz Suassuna (2010), em comentário sobre o poema aqui analisado:

A presença da linguagem metafórica no meu soneto - como aliás, em tudo que eu escrevo - vem do meu cristianismo e da minha convivência, desde menino, com os grandes profetas judeus, principalmente Ezequiel, Isaías e Daniel. A Estrela é, portanto, uma imagem na qual procuro sempre fundir a Estrela de David com a Estrela da Manhã, a Sofia e a Mulher Vestida de Sol.

A face do sagrado da obra do poeta está, portanto, totalmente ligada ao imaginário cristão e, em grande parte, também à tradição judaica. As alusões bíblicas são mais frequentes no segundo álbum, tornando-se chaves fundamentais para seus sonetos. A Estrela da Manhã, que Suassuna cita em seu comentário, pode ser associada a Vênus, planeta tipicamente ligado ao feminino, mas também a Jesus Cristo, como afirmado em Apocalipse 22:16: "Eu, Jesus, enviei o meu anjo para dar a vocês este testemunho concernente às igrejas. Eu sou a Raiz e o Descendente de Davi, e a resplandecente Estrela da Manhã". Também está citada no livro do Apocalipse a já comentada figura da Mulher Vestida de Sol.

A Estrela de Davi, também referida no comentário de Suassuna, é um símbolo antigo que porta muitos significados. No livro bíblico de 
Samuel, há a história do rei Davi, a quem se associa a estrela de seis pontas como símbolo de identificação das armas. Os dois triângulos invertidos comumente também representam a união entre o feminino e o masculino, o que condiz com a vontade de Suassuna de buscar a face feminina e materna do sagrado:

Bom, eu digo que a visão judaica de Deus é muito masculina e paterna, não é? (...) E eu sentia falta, exatamente, da presença feminina e materna em Deus. Foi isso que eu encontrei na figura de Nossa Senhora, está certo? Era uma coisa da qual eu sentia falta e que eu vim encontrar na figura dela. Depois eu examinando, já como adulto, eu lendo a Bíblia, descobri que o Velho testamento já apresenta uma pré-figuração de Nossa Senhora. É num livro chamado Livro da sabedoria. Esse livro é um livro muito estranho, porque começa a se falar da sabedoria de Deus, que em grego é sophia, não é? Daí o pessoal fala na Santa Sofia e o pessoal pensa que é uma mulher determinada, mas não, a Santa Sofia é a santa sabedoria de Deus (SUASSUNA, 2015, p. 81).

Segundo Campbell (1997, p. 95), por volta de 3500 a.C. houve uma alteração do

conceito anterior da Deusa como causa única e a própria essência do corpo deste universo para uma maneira indoeuropeia ou semítica dualista de simbolização, na qual ela não é mais, em si mesma e sozinha, 'Grande', mas sim consorte de um 'Grande' Deus.

O autor exemplifica esta transição, em que a antiga Deusa Mãe passa a ser vista como co-criadora do universo ao lado de uma figura masculina, justamente com uma passagem bíblica sobre a sabedoria, em Provérbios 8:1. Ao buscar uma presença feminina em Deus, faz sentido então que Suassuna se volte para a Sofia, a figura da santa 
sabedoria divina e feminina. Ela que é não só uma divindade poderosa, como também co-criadora do mundo.

No primeiro terceto do poema há mais um hipertexto de origem bíblica: quem transforma o sangue em Candelabro e Veiro por sobre a dor é a Sarça do Espinheiro, alusão a um elemento importante do Velho Testamento. A história da Bíblia diz que Moisés caminhava sozinho e foi atraído por uma planta, pela sarça do espinheiro, que, estando em chamas, não era consumida pelo fogo. Foi através dessa planta que Deus falou com Moisés. A chama que não se apaga é luz na escuridão e promessa de imortalidade, anúncio de triunfo da arte e da Beleza contra a morte. Aliada à sabedoria comentada no parágrafo anterior, é a arte que permite ao poeta a possibilidade de afirmar, no verso final do soneto: "sou contra a Morte e nunca hei de morrer".

Apesar de libertador e ligado aos dons divinos, no soneto "Abertura 'sob pele de ovelha", o dom da escrita parece ser de certa maneira torturante, doloroso. Sobre isso, Gustavo Bernardo (2010, p.20) diz: "A ficção é menos uma diversão do que um escudo contra as ameaças externas e internas, obrigando-nos a narrar uma luta interminável: o drama que nos constitui”.

E é realmente sobre este drama que o constitui que fala Suassuna em sua poesia. Percebe-se, logo na primeira estrofe e especialmente pela escolha lexical, referências ao momento da perda de seu pai. Falamos em escolha lexical porque, ao longo do primeiro álbum de iluminogravuras, Suassuna constrói uma conexão forte entre a dor do luto pela morte do pai e um estado de "cegueira". 
Mas, aqui, há uma diferença importante em relação a outros poemas que também referenciam esse trauma. Se, no primeiro álbum de iluminogravuras, há um percurso de reflexão sobre a morte que vai desde o desespero até o encontro com Deus, nesta “Abertura”, vê-se, de certa maneira, a síntese total da questão: o dom da escrita, o seu cantar, é o trunfo maior do poeta contra a morte, e esta não poderá mais derrotá-lo. O soneto aqui analisado não está no livro Vida Nova Brasileira, o que sugere uma criação posterior. É como se o "sob pele de ovelha", fosse também um anúncio de renovação, de encantamento e de compreensão do ato artístico, do fazer poético.

\section{Considerações finais}

Trabalhar com as iluminogravuras de Suassuna é um desafio, cada uma delas se apresenta como um enigma próprio a ser decifrado. Além disso, esse não é um tema que foi muito estudado, havendo, até o momento, pouca produção bibliográfica sobre essas criações do poeta paraibano. Desde a primeira parte do trabalho, fica claro que elas se inserem em um projeto maior, que é também o projeto do Movimento Armorial.

Ao expor a história do movimento junto ao processo que culminou na elaboração do corpus desta pesquisa, percebe-se que os álbuns iluminogravados são bastante representativos dos dois princípios fundamentais do Armorial: a criação de arte erudita brasileira baseada na arte popular e a valorização da integração entre as artes. Esse projeto maior, que é de arte, mas também foi de vida para 
Suassuna, consegue envolver toda a produção dele em um enorme mosaico em que cada parte ajuda a compor um belo e coeso resultado final.

Propusemos uma dentre as infinitas leituras possíveis para essas iluminogravuras. A partir da escolha dos três eixos temáticos - morte, feminino e sagrado - como guias, podemos dizer que a "linha narrativa" presente nesses trabalhos se torna mais significativa. A morte claramente é o tema que une todos os outros . Mas, a relação do poeta com esse tema principal sofre rigorosas mudanças ao longo da leitura. Em o "Sol de Deus", soneto final do primeiro álbum, a morte já aparece associada a um encontro futuro. No segundo álbum, surgem mais duas alterações de perspectiva: a primeira é que, através do encontro com a mulher, alcança-se o sagrado. A morte passa a ser, de certa maneira, até desejada, pelo encontro que representará com o Deus de amor. O combate à morte se faz finalmente pela fé no sagrado, mas não só por isso. Há uma sensação final de continuidade, pelo sangue da herança e pela arte, o cantar que imortaliza e garante a permanência.

\section{Referências}

ANJOS, A. Eu e outras poesias. São Paulo: Martins Fontes, 2001.

BERNARDO, G. O livro da metaficção. Rio de Janeiro: Tinta Negra Bazar Editorial, 2010.

BUORO, A. B. Olhos que pintam: a leitura da imagem e o ensino da arte. São Paulo: Cortez, 2003.

CAMPBELL, J. Todos os nomes da Deusa. Rio de Janeiro: Record, 1997. 
DERRIDA, J.; ROUDINESCO, E. De que amanhã... Diálogo. Rio de Janeiro: Jorge Zahar, 2004 .

ECO, U. Lector in fabula: a cooperação interpretativa nos textos narrativos. São Paulo: Perspectiva, 2012.

GENETTE, G. Palimpsestos: a literatura de segunda mão. Belo Horizonte: Edições Viva Voz. 2010

GONÇALVES, A. J. Laokoon revisitado: relações homológicas entre texto e Imagem. São Paulo: Editora EDUSP, 1994.

HOEK, L. H. 2006. A transposição intersemiótica: por uma classificação pragmática. In: Poéticas do visível: ensaios sobre a escrita e a imagem. Márcia Arbex (org.). Programa de Pós-graduação em Letras: Estudos Literários, Faculdade de Letras, Universidade Federal de Minas Gerais. 167-189.

HOLANDA, L. Ariano Suassuna, cavaleiro andante da cultura brasileira. In: NOGUEIRA, M. A. L. (Org.). Ode a Ariano Suassuna: celebrações dos 80 anos do autor na Universidade Federal de Pernambuco. Recife: Ed. Universitária da UFPE, 2007. p. 11-31.

LIMA, G. C. O Gráfico Amador: As origens da moderna tipografia brasileira. Rio de Janeiro: Verso Brasil, 2014.

MANGUEL, A. Lendo imagens: uma história de amor e ódio. Tradução Rubens Figueiredo. São Paulo: Companhia das Letras, 2009.

NEWTON JÚNIOR, C. Ariano Suassuna, artista plástico. In: ZACCARA, M.; CARVALHO, L. M. (Org.). Paisagens plurais: artes visuais \& transversalidades. Recife: Ed. Universitária da UFPE, 2012. p. 111-133.

Novo Almanaque Armorial. As três fases do Movimento Armorial. In: Correio das Artes, João Pessoa, dezembro/2011, ano LXII, nำ10, p. 40-41, 2011.

O Pai, o Exílio e o Reino: A Poesia Armorial de Ariano Suassuna. Recife:

Ed. Universitária da UFPE, 1999. 
PAZ, O. Signos em rotação. Tradução Sebastião Uchoa Leite. São Paulo: Perspectiva, 1996.

SANTOS, I. M. F. Em demanda da poética popular: Ariano Suassuna e o Movimento Armorial. Campinas: Editora da Unicamp, 2009.

SUASSUNA, A. A pintura armorial. Edição de Arte, Recife, mar. 1989.

Ariano Suassuna expõe iluminogravuras: entrevista. [5 de junho, 2008b]. Disponível em: http://www.nordesteweb.com/not10_1203/ne_not_20031205b.htm. Entrevista concedida a Ângela Lacerda. 3964. Recife: 1977b.

Dez Sonetos com Mote Alheio. Recife: edição manuscrita e iluminogravada pelo autor, 1980 .

Entrevista: Ariano Suassuna. [2010]. São Paulo: Blog A Besta Esfolada. Disponível em: http://bestaesfolada.blogspot.fr/2010/o8/ariano-suassuna-sobpele-de-ovelha.html. Entrevista concedida a Paulo Valadares.

. Entrevista: Ariano Suassuna. [2011]. Porto de Galinhas: Jornal da BEP. Disponível em: https://www.youtube.com/watch?v=jUfXteQZq3U. Último acesso em julho de 2015 .

. Entrevista: Ariano Suassuna. [2015]. Teresina: Revista Hoblicua. Entrevista concedida a Douglas Machado.

Ferros do Cariri: uma heráldica sertaneja. Recife: Guariba Editora de Arte, $1974 a$.

O Movimento Armorial. Recife: Editora Universitária da UFPE, 1974b.

O Movimento Armorial. Separata da Revista Pernambucana de Desenvolvimento. p. 3964. Recife: 1977b.

. Sonetos de Albano Cervonegro. Recife: edição manuscrita e iluminogravada pelo autor, 1985 .

Uma mulher vestida de sol. Rio de Janeiro: José Olympio, 2003. 
VARGA, A. K. Entre le texte et l'image: une pragmatique des limites, in Text and Visuality Word \& Image, no3. Amsterdam: Editions Rocopi B.V., 1999. p.77-92.

Recebido em 06/10/2017.

Aprovado em 09/10/2017. 